\title{
Pablo, maestro de exégesis bíblica, según Orígenes
}

\author{
Samuel Fernández Eyzaguirre \\ FACULTAD DE TEOLOGÍA \\ PONTIFICIA UNIVERSIDAD CATÓLICA DE CHILE \\ sfernane@uc.cl
}

El lector moderno experimenta grandes dificultades frente a la exégesis origeniana: le parece que ella nace más de la imaginación del intérprete que del examen del texto. Por ello, para comprender la interpretación bíblica de Orígenes, es necesario ubicarla en su contexto, mostrar las motivaciones que la impulsan y mostrar los modelos en que se apoya: uno de estos modelos es el apóstol Pablo ${ }^{1}$.

\section{NeCESIDAD DE LA EXÉGESIS ESPIRITUAL EN LA IGLESIA PRIMITIVA}

La Iglesia se situaba en diálogo y polémica con diversos grupos: los judíos, los gnósticos y marcionitas, y los paganos. Pero Orígenes, dada su intención de ofrecer una versión del cristianismo aceptable para los griegos instruidos de la sociedad alejandrina, se enfrenta con un cuarto grupo, los que él denomina "los simplones".

a. La comunidad cristiana primitiva compartía las escrituras con el judaísmo. Con esas escrituras debían probar que Jesús era el Mesías. Pero los textos tradicionalmente considerados mesiánicos no contenían nada acerca de la pasión y de la resurrección, por ello, se debía ampliar la base bíblica para demostrar la mesianidad de Jesús de Nazaret. La interpretación simbólica de los textos se vuelve una necesidad para alcanzar este objetivo. De este modo se comenzó a interpretar simbólicamente una buena cantidad de textos del Antiguo Testamento (AT). En este contexto, Pablo utiliza el

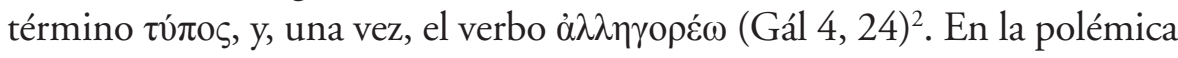

\footnotetext{
1 Este artículo forma parte de los resultados del proyecto Fondecyt 1120687: Interacción del pensamiento cristiano y helenístico en el De principiis de Orígenes de Alejandría.

2 Cf. M. Simonetti, Lettera elo allegoria. Un contributo alla storia dell'esegesi patristica (Roma 1985) 24-25, nota 32.
} 
entre judíos y cristianos en el siglo II, los cristianos ampliaban la interpretación simbólica de la escritura para afirmar la mesianidad de Jesús, mientras los judíos con una exégesis literal negaban el carácter mesiánico de Jesús. Las fuentes permiten reconstruir un cierto dossier de textos que los judíos utilizaban en su polémica contra los cristianos, para mostrar que lo que se anuncia en la escritura acerca de la era mesiánica no ha sucedido ${ }^{3}$.

b. Por otra parte, en la medida en que la primera Iglesia se abre al mundo pagano, la componente judía al interior de la comunidad se vuelve marginal y la vinculación con el AT se hace más débil. Un pagano convertido al cristianismo se siente ajeno a la Escritura de los judíos. Él preferiría quedarse solo con el Nuevo Testamento (NT), más comprensible, fácil y breve. Surge así, al interior de la Iglesia, una corriente que tiende a desentenderse del AT. Esta tendencia, presente entre los católicos ${ }^{4}$, será llevada al extremo por los gnósticos y más aún por los marcionitas. Marción afirma que los mensajes del AT y NT son irreconciliables y que, por lo tanto, provienen de dioses distintos y opuestos: el evangelio se opone a la ley. Así lo declara Tertuliano: "La separación de la Ley y el Evangelio es la tarea propia y principal de Marción", por ello compuso las Antítesis "que intentan mostrar la discordia del evangelio con la ley" 5 . Por este motivo, Marción rechaza la alegoría ${ }^{6}$, pues sobre la base de una exégesis literal podía mostrar la discordia entre el AT y el NT.

3 Cf. Is 11, 6-7; 61, 1; Ez 48, 15; Zac 9, 10. Se puede apreciar la presencia de estas mismas citas bíblicas, por ejemplo, en Justino, Diálogo con Trifón, Tertulliano, Adversus Iudaeos y Orígenes, Princ., IV, 2, 1.

4 Así Ignacio de Antioquía se mostrará poco interesado por el Antiguo Testamento, cf. A los Filadelfios VIII,2. Por su parte, el Ps.-Bernabé desconocerá el valor literal de la ley, Epístola, IV, 6-7; XIV, 1-4; IX, 1-6; X, 1-12.

5 Cf. Tertuliano, Adversus Marcionem, I, 19, 4: "La separación de la Ley y el Evangelio es la tarea propia y principal de Marción (Separatio legis et evangelii proprium et principale opus est Marcionis), sus discípulos no pudieron negar lo que poseen al inicio del documento (instrumentum), por el que son iniciados y fortalecidos en esta herejía. Estas son las Antítesis de Marción, es decir, las oposiciones de [afirmaciones] contrarias (id est contrariae oppositiones), que intentan mostrar la discordia del Evangelio con la Ley, de modo que, basándose en la diversidad de las afirmaciones de uno y otro documento, se pruebe la diversidad de los dioses" (CCL I, 460). Las traducciones son propias.

6 Orígenes se refiere a Marción como "cui per allegoriam nihil placet intellegi", In Rom. Com., II,13 (PG XIV,910a); cf. A. v. HarnaCK, Marcion. Das Evangelium vom fremden Gott (TU, 45, Leipzig 1924) 260*-261*. 
c. El tercer grupo ante el cual se sitúa la Iglesia son los paganos, que también proponen dificultades respecto de la Escritura. La actitud de un pagano culto, hostil a la Biblia, está representada por Celso, filósofo neoplatónico, que por el año 175 escribió el Discurso verídico, que consiste en una despiadada crítica del cristianismo y del judaísmo ${ }^{7}$. Celso ridiculiza la escritura y se refiere al relato de la creación como "la leyenda más absurda y sin gracia de cierto hombre plasmado por las manos de Dios e insuflado; de una mujer sacada del costado del hombre"8. Respecto de los seis de la creación, se pregunta: "QQué días podía haber cuando no se habia creado aún el cielo, ni estaba asentada la tierra, ni el sol giraba en torno a ella?"'. La lectura literal de la escritura ofrece a Celso abundante material para la sátira: ridiculiza los episodios del Arca de Noé, de las hijas de Lot, de las inmoralidades de los patriarcas, etc. ${ }^{10}$. Celso critica el carácter antropomórfico del Dios de la escritura, de un Dios que "se irrita, se enfurece y amenaza" ${ }^{11}$. Afirma también que los evangelios se contradicen $^{12}$. Celso sabe que judíos y cristianos recurrían a la alegoría, para resolver sus dificultades, pero rechaza su proceder:

"Los moderados entre judíos y cristianos tratan de explicar todo esto alegóricamente, avergonzados de tales historias, buscando refugio en la alegoría [...]. Pero hay cosas que no admiten alegoría, sino que son cuentos simplemente tontísimos"13.

En síntesis, el arma que le permite ridiculizar las afirmaciones bíblicas es, una vez más, la interpretación literal.

d. El último grupo, los simpliciores, son cristianos que miran con desconfianza la razón, prefieren una fe ciega y practican la lectura literal

7 Orígenes respondió este ataque en su célebre Contra Celso, escrito por el año 235.

En él se conservan numerosos fragmentos que permiten reconstruir el Discurso verídico. Abundante información sobre Celso se encuentra en A. Le Boulluec, Vingt ans de recherches sur le Contre Celse: état des lieux, en Discorsi di Verità. Paganesimo, giudaismo e cristianesimo a confronto nel Contro Celso di Origene. A cura di L. Perrone (Roma 1998) 9-28; S. Benko, «Pagan Criticism of Christianity During the First Two Centuries A.D.», en ANRW, II 23/2 (Berlin-New York 1980) 1055-1118.

8 Orígenes, C. Cels., IV,36 (GCS, I 306).

9 Orígenes, C. Cels., VI,60 (GCS, II 130); cf. VI,49-50.61.

10 Cf. Orígenes, C. Cels., IV,41-47.

11 Orígenes, C. Cels., IV, 73 (GCS, I 342); IV, 72; VIII, 13.

12 Cf. Orígenes, C. Cels., II, 27.

13 Orígenes, C. Cels., IV, 48.50 (GCS, I 320.323); cf. I, 27; IV, 51. 
de la escritura ${ }^{14}$. Orígenes no solo percibe el peligro que los gnósticas representan para el evangelio, sino que también reconoce que una presentación demasiado simple del cristianismo, lo que él llama "una fe

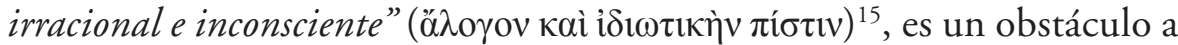
la expansión del mensaje evangélico. Estos cristianos se conforman con el sentido literal de la escritura y, por ello, según Orígenes, "piensan acerca de Dios cosas que no se podrían pensar ni siquiera del más injusto de los hombres" ${ }^{16}$, y creen "fábulas estúpidas" ${ }^{17}$. Estos cristianos están presentes en las asambleas en que predica Orígenes y se oponen a los intentos del predicador de profundizar en la escritura. Una homilía sobre los pozos de Jacob retrata la situación:

"Si yo quisiera excavar hacia lo profundo y abrir las escondidas venas de agua viva, al instante se presentarán los filisteos y me combatirán, se reirán de mí, levantarán calumnias y comenzarán a llenar mis pozos con su tierra y su lodo [...]. Pero si yo quisiera interrogar a la Palabra de Dios sobre esto e investigar, inmediatamente los filisteos levantarían disputas y calumnias contra mî" ${ }^{18}$.

Estos filisteos, que cubren con tierra los pozos excavados por Jacob, naturalmente simbolizan a los simplones (simpliciores), que imponen una interpretación bíblica de tipo literal (= tierra) y se oponen a que Orígenes acceda al sentido espiritual de la Escritura (= agua del pozo) ${ }^{19}$. El texto es interesante porque muestra el ambiente polémico en que Orígenes desarrolla su actividad exegética.

Las dificultades de tres de estos grupos son explícitamente descritas al inicio de De principiis IV,2, el primer tratado cristiano de hermenéutica bíblica que se conserva, mientras el cuarto, los paganos, sin estar explícitamente mencionado, está presente por medio de la respuesta a sus objeciones. Mientras los judíos no han creído en Jesús como Mesías,

14 Cf. G. af Hällström, Fides Simpliciorum according to Origen of Alexandria (Helsinki 1984).

15 Orígenes, In Ioh. Com., V, fr. VIII (GCS, IV 105).

16 Orígenes, Princ., IV, 2, 1 (GCS, V 308).

17 Cf. Orígenes, In Ct. Com., prol., II,14; In Mt. Com., XVII, 35.

18 Orígenes, In Gen. hom., XII, 4 (GCS, VI 110).

19 Cf. Orígenes, In Gen. hom., VI, 3; XIII, 3; In Nm. hom., XII, 2. En otro contexto, los filisteos representan a los judíos que no permiten que se excaven los pozos del Nuevo Testamento, cf. In Gen. hom., XIII. 
porque no han visto realizadas literalmente las profecías acerca de él, pues no han visto sensiblemente liberados a los prisioneros (Is 61, 1), ni la edificación de la ciudad de Dios (Ez 48, 15ss), ni la destrucción de los carros de Efraín (Za 9, 10), ni al león paciendo con el buey (Is 11, 6-7), entonces "no aceptaron a nuestro Señor Jesús, sino que lo crucificaron como a uno que ilegitimamente se había autoproclamado Cristo" 20 . Los herejes, por su parte, cuando leen "Yo soy un Dios celoso, que castiga los pecado de los padres en los hijos, hasta la tercera y cuarta generación"21, rechazaron al Creador, como un dios imperfecto, y afirmaron que el Salvador ha venido a anunciar un Dios más perfecto, diferente del Creador ${ }^{22}$. Y los simples, que aceptan al Dios Creador del AT, piensan sobre él lo que ni siquiera se podría pensar acerca del hombre más cruel e injusto ${ }^{23}$. Por ello, Orígenes concluye:

"La causa de las falsas opiniones y de los discursos impíos y vulgares acerca de Dios de todos los que han sido mencionados no parece ser ninguna otra que la escritura no comprendida según lo espiritual, sino acogida en cuanto a la pura letra" 24 .

Según Orígenes, las dificultades frente a los judíos, a los herejes y a los simples se resuelven por medio de la exégesis espiritual. Asimismo, las objeciones paganas a la escritura, por ejemplo, las referidas a los relatos de la creación, también son resueltas sobre la base de la interpretación espiritual de los textos.

En síntesis, según Orígenes, a causa de la exégesis literal, los judíos rechazan a Jesús, los herejes rechazan al Creador y al AT, los simples denigran a Dios y los paganos rechazan tanto el AT como el NT. Esta introducción permite comprender hasta qué punto el modo de interpretar la escritura, para la Iglesia de los siglos II y III, no era una discusión académica o de escuelas, sino una cuestión de vida o muerte, en la que se jugaba la identidad y la fisonomía de la comunidad cristiana.

\footnotetext{
20 Orígenes, Princ., IV, 2, 1 (GCS, V 307).

21 Éx 20, 5.

22 Cf. Orígenes, Princ., IV, 2, 1.

23 Cf. Orígenes, Princ., IV, 2, 1.

24 Orígenes, Princ., IV, 2,2 (GCS, V 308).
} 
II. Pablo, maestro de exégesis espiritual

En este tenso y polémico ambiente, Orígenes encuentra en Pablo un aliado que le permite otorgar autoridad y justificar la exégesis espiritual de la escritura ${ }^{25}$. Esta opción por apoyarse en este apóstol, muestra que en el ambiente de Orígenes la autoridad de Pablo ya estaba bien reconocida, y que los grupos que rechazaban al Apóstol eran considerados ajenos a la Iglesia.

Por una parte, Orígenes presenta como paradigmáticos ciertos ejemplos paulinos de interpretación bíblica; por otra parte, identifica ciertos versículos de las cartas Pablo como reglas de interpretación bíblica; y, finalmente, presenta a Pablo como ejemplo de hombre espiritual que accede al contenido espiritual de la escritura.

1. Ejemplos de exégesis paulina que Orígenes considera programáticos

El desarrollo fundamental en que Orígenes presenta la exégesis paulina como ejemplo de exégesis cristiana es De principiis IV, 2, 6. Después de proponer su teoría de los tres niveles de la comprensión de la escritura: de acuerdo al cuerpo (literal), de acuerdo al alma (moral) y de acuerdo al espíritu (espiritual), el alejandrino presenta a Pablo como modelo del segundo y tercer nivel:

"Como paradigma de la explicación referida al alma estaría lo que, en Pablo, se encuentra en la primera a los Corintios: «Pues -dice- está escrito: 'No pondrás bozal al buey que trilla» ${ }^{26}$. Luego, explicando esta ley, propone: "¿Acaso Dios se preocupa de los bueyes?, ¿o habla solamente por nosotros? Ciertamente, se escribió por nosotros, porque el que ara debe arar en esperanza, y el que trilla, en la esperanza de recibir su parte» ${ }^{27}$. Y muchas interpretaciones que circulan, que son adecuadas para la mayoría, y que edifican a los que no son capaces de escuchar [interpretaciones] más elevadas, tienen de algún modo el mismo carácter" ${ }^{28}$.

25 Cf. F. Cocchini, Il Paolo di Origene. Contributo alla storia della ricezione delle epistole paoline nel III secolo (Studium, Roma 1992) 117-148.

26 1Co 9, 9; Dt 25, 24. Cf. 1Tim 5, 18.

27 1Co 9, 10 .

28 Orígenes, Princ., IV, 2, 6 (GCS, V 316). 
Se trata de un ejemplo de exégesis moral, porque si bien el contenido del texto no se identifica con su letra, todavía se mantiene en el nivel moral y no implica los misterios más profundos. El texto de Dt 25, 24, que en sí mismo no tiene sentido (pues Dios no se ocupa de los bueyes), es interpretado por Pablo como una regla moral. Lo interesante es que, en esta práctica paulina, Orígenes ve un paradigma, es decir, un modelo de comprensión de la ley de Moisés.

A continuación, como ejemplo de interpretación espiritual, propone el conocido comentario de Pablo a la salida de Egipto y la marcha de Israel por el desierto:

"El mismo apóstol [Pablo], valiéndose de algunas expresiones tomadas del Éxodo y de los Números, dice: "Estas cosas les acontecían a ellos de modo tipológico, fueron escritas en función de nosotros, para los que han alcanzado el final de los siglos» ${ }^{29}$. Y ofrece los puntos de partida [para entender] de qué eran typos aquellos [acontecimientos], cuando dice: "Pues, bebian de la roca espiritual que los seguía, y la roca era Cristo»" 30 .

Orígenes valora muchísimo esta interpretación paulina, que la considera un modelo que Pablo propone para interpretar los libros de la Ley. En una homilía sobre el Éxodo, expresa esta convicción:

"El Doctor de los pueblos en la fe y en la verdad, el apóstol Pablo ha transmitido a la Iglesia, cómo deben ser usados los libros de la Ley [...]. Por eso él mismo, en algunos pasajes, pone ejemplos de interpretación, para que nosotros actuemos de modo semejante en otros casos [...]. Pues los judíos entienden simplemente que los hijos de Israel partieron de Egipto, que su primera partida fue desde Ramsés, que desde allí llegaron a Sukot, y que de Sukot llegaron a Etam cerca de Epauleum junto al mar; después entienden sin más, que allí les precedió la nube y les siguió la roca, de la que bebían el agua, que pasaron a través del mar Rojo y que llegaron al desierto del Sinaí. Nosotros veamos qué regla para interpretar estas cosas nos ha transmitido el apóstol Pablo. Escribiendo a los corintios en algún pasaje dice así: «En efecto, sabemos que todos nuestros antepasados estuvieron bajo la nube, y que todos fueron bautizados en Moisés en la nube y en el mar, y todos comieron la misma comida espiritual y bebieron la misma bebida espiritual. Bebían de la roca espiritual que

29 1Co $10,11$.

30 Orígenes, Princ., IV, 2, 6 (GCS, V 316); 1Cor 10, 4. 
les seguía; esta roca era Cristo». Ya veis cuánto se distingue la lectura histórica de la interpretación de Pablo: lo que los judíos piensan que es el paso del mar, Pablo lo llama bautismo; lo que ellos consideran nube, Pablo lo presenta como el Espíritu Santo"31.

Lo que más nos interesa es el hecho que Orígenes ve en este texto de 1 Cor 10 una "regula inteligentiae" de los libros de la ley proporcionada por Pablo, al que llama "Doctor gentium in fide et veritate". Por ello, posteriormente, pregunta al auditorio:

"¿Qué haremos, pues, nosotros que hemos recibido de Pablo, maestro de la Iglesia, tales enseñanzas de interpretación? ¿Acaso no es justo que observemos en diversos casos esta regla que nos ha transmitido en un ejemplo similar? ¿ O bien, como algunos quieren, debemos volver a las fábulas judaicas, abandonando lo que nos ha transmitido tan grande e ilustre Apóstol? [...] Por tanto, cultivemos las semillas de la inteligencia espiritual recibidas del santo apóstol Pablo"32.

Lo propio de la comprensión origeniana del pasaje paulino de 1Co 10 es afirmar que el texto ofrece una regla que se debe aplicar sistemáticamente en la interpretación del AT. De hecho, tanto las homilías sobre el Éxodo como en las sobre los Números, interpreta espiritualmente la caminata de Israel por el desierto, y más ampliamente la historia del pueblo de Dios.

Otro texto que Orígenes considera como una demostración de la legitimidad de la interpretación alegórica del AT es el pasaje de Gál 4, 21-24:

"Además, en la carta a los Gálatas, como reprochando a los que presumen leer la ley y no la comprenden, juzgando que aquellos no comprenden, en la medida que suponen que no hay alegorías en las escrituras: "Decidme -afirma- los que queréis estar bajo la ley, ¿no habéis escuchado la ley? Pues, está escrito que Abraham tuvo dos hijos: uno de la esclava y uno de la libre. Pero el de la esclava nació de acuerdo a la carne, mientras el de la libre, [nació] a causa de la promesa. Estas cosas son dichas alegóricamente, pues ellas equivalen a las dos alianzasi" ${ }^{33}, \mathrm{y}$ lo que sigue" ${ }^{34}$.

31 Orígenes, In Ex. hom., V, 1 (GCS, VI 183-184).

32 Orígenes, Ex. hom., V, 1 (GCS, VI 184-185).

33 Gál 4, 21-24.

34 Orígenes, Princ., IV, 2, 6 (GCS, V 316-317). 
El pasaje de Gálatas es el único lugar de Nuevo Testamento donde se usa el término $\dot{\alpha} \lambda \lambda \eta \gamma o \rho \varepsilon ́ \omega$, lo que ofrece una base a Orígenes para otorgar autoridad al método de interpretación alegórico, tan común en el ambiente alejandrino. Pero el hecho de que Pablo, en el mismo texto,

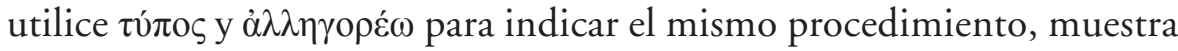
que no se debe establecer una división entre el método alegórico y el tipológico. Orígenes no diferencia tipología de alegoría: la distinción entre método tipológico (que no anularía la historia) y el método alegórico (que anularía la historia) es obra de los estudiosos del siglo XX. Según el Alejandrino, la escritura siempre tiene sentido espiritual, si bien no siempre tiene sentido literal. Ahora bien, a propósito de Gál 4, 24, Orígenes va más allá de la afirmación de Pablo, y la universaliza:

"Entonces, tú podrías investigar si el escriba de la Ley es como el escriba del Evangelio: y tal como el que lee y escucha la Ley y afirma: "Estas cosas están dichas como alegorías", lo mismo [afirme el que lee y escucha] el Evangelio"35.

De acuerdo al uso del autor, que propone sus tesis como preguntas, Orígenes considera que la afirmación paulina, "estas cosas están dichas como alegorías", no solo se debe aplicar a la ley, sino también a los evangelios. Pero, esta interpretación alegórica, no anula la historia, tal como lo afirma en el Comentario a Mateo:

"Pues todas ( $\pi \alpha ́ v \tau \alpha)$ las sanaciones que Jesús realizó en medio del pueblo, principalmente las que han sido escritas por los evangelistas, sucedieron en aquel tiempo ( $\tau$ ó $\tau \varepsilon)$ para que creyeran los que no creen sin ver signos y prodigios; pero las cosas que sucedían en aquel tiem-

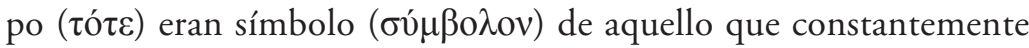
(ảeí) es realizado por la virtud de Jesús. Pues no hay ni un momento

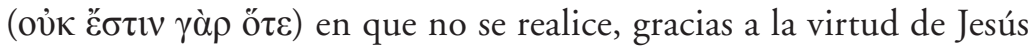
y de acuerdo con la dignidad de cada uno, cada cosa que ha sido escrita" 36 .

La novedad de Orígenes es su sistematicidad en la interpretación espiritual de las narraciones bíblicas. Pero, a la vez, este texto muestra claramente que la convicción origeniana de que el evangelio ha sido dicho como alegoría, en ningún caso pone en duda el carácter histórico del

35 Orígenes, In. Mt. Com., X, 14 (GCS, X 17).

36 Orígenes, In Mt. Com., XI,17 (GCS, X 62). 
evangelio ${ }^{37}$. Lo que le interesa, es la relevancia del evangelio, y un puro recuerdo de lo que realizó Jesús no es útil al lector, y-como veremos más adelante- Orígenes valora mucho la afirmación paulina: "Toda escritura inspirada es útil" (2Tim 3, 16). De hecho, la interpretación espiritual, en este caso, de las sanaciones permite darles un significado actual, y así edificar al oyente. Orígenes se dirige a su auditorio: "También tú has sido sanado por el Salvador..." 38 , y a propósito de la resurrección de Lázaro, afirma "es necesario saber que también hoy hay algunos Lázaros que, después de la amistad con Jesuis, se han enfermado y han muerto..." ${ }^{39}$.

Además de estos centrales ejemplos paulinos de interpretación espiritual, Orígenes ofrece otros menores. La necesidad de remover el velo de la escritura, de acuerdo a 2Co 3, 12-18 (cf. Princ., IV, 1, 6). Orígenes destaca que Pablo afirma que las prescripciones rituales "son sombra de las realidades futuras" ${ }^{40}$, y recuerda que, cuando Pablo expuso lo referente a la tienda, transmitió la frase: "Harás todo de acuerdo al typos que te fue mostrado en el monte" 41 . Orígenes también destaca que el Apóstol dice: "Observad a Israel según la carne" 42 , para invitar nuestra inteligencia a elevarse y a reconocer que hay otro Israel, según el espíritu; que Pablo afirma que Adán es typos de Cristo y Eva es typos de la Iglesia ${ }^{43}$; y que Pablo habla de la Jerusalén de arriba ${ }^{44}$. Finalmente, el Alejandrino recuerda que Pablo, en Rom 11, 4, también interpreta de modo espiritual un texto que no pertenece a los libros de Moisés, sino al 3Reyes 19, 18 LXx (1Re 19, 18), lo que indica su convicción de que se debe extender a toda la historia de Israel la interpretación espiritual practicada por Pablo ${ }^{45}$.

\footnotetext{
37 Cf. S. Fernández, Cristo Médico, según Orígenes. La actividad médica como metáfora de la acción divina (Roma 1999) 61-71; 255-264.

38 Orígenes, In Ct. hom., II,4 (GCS, VIII 49).

39 Orígenes, In Ioh. Com., XXVIII,viI, 54 (GCS, IV 397).

40 Orígenes, Princ., IV, 2, 6 (GCS, V 317); Col 2, 17.

41 Cf. Orígenes, Princ., IV, 2, 6; Heb 8, 5; 9, 24; 10, 1.

42 1Co 10, 18. Cf. Orígenes, Princ., IV, 3, 6.

43 Cf. Orígenes, Princ., IV, 3, 7; 1Co 15, 47; Ef 5, 31-32.

44 Cf. Orígenes, Princ., IV, 3, 8: Gál 4, 26; Heb 12, 22-23.

45 Cf. Orígenes, Princ., IV, 2, 6.
} 
2. Versículos paulinos que Orígenes comprende como reglas de interpretación

a. "Comparando realidades espirituales con realidades espirituales" (1Co 2, 13)

Se trata de un versículo muy frecuente en la obra de Orígenes, en especial, en contexto exegético ${ }^{46}$. Naturalmente, recuerda la regla de los filólogos alejandrinos: "Aclarar Homero con Homero" ${ }^{47}$, pero contiene una interesante diferencia, puesto que para Orígenes, Pablo no invita a comparar la letra con la letra, sino las realidades espirituales con las espirituales. En otro texto del De principiis IV, 2, 6 aclara el motivo:

"Puesto que, como será evidente para los lectores, la coherencia

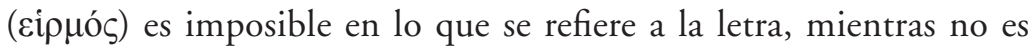
imposible, sino además verdadero el [sentido] principal, hay que esforzarse para comprender todo el sentido, conectando ( $\sigma v v \varepsilon i ́ p o v \tau \alpha)$

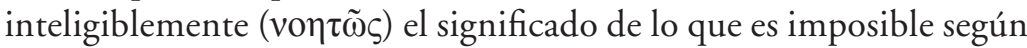
la letra con lo que no solo no es imposible, sino que, según la historia, es también verdadero, lo que se comprende de modo alegórico junto con aquello que no ha sucedido en la letra. Pues, acerca de toda la divina escritura, se nos presenta que toda ella tiene [sentido] espiritual, mientras no toda tiene [sentido] corporal. Pues en muchos lugares se demuestra que es imposible lo corporal".

A Orígenes le interesa mostrar que la Escritura es coherente consigo misma, coherencia que era negada por Marción (que, a partir de una lectura literal de los textos, buscaba mostrar que hay contradicción entre AT y NT) y por Celso (también sobre la base de una lectura literal). Por eso Orígenes busca la coherencia no a nivel de la letra, sino a nivel del espíritu. De este modo, entre dos relatos, se debe comparar lo espiritual con lo espiritual. Así lo afirma al proponer una regla de interpretación bíblica, durante una homilía:

"Para que conozcamos de modo más pleno el contenido interior de esta palabra, creo que es conveniente presentar de la divina Escritu-

46 OríGenes comprende $\pi v \varepsilon v \mu \alpha \tau$ ikoĩ como neutro plural (las realidades espirituales), a diferencia de Ps.-Hipólito, que lo comprende como masculino plural (los hombres espirituales), cf. Refut. V, 8, 26; F. Cocchini, Il Paolo di Origene, 119-120.

47 Para este principio exegético, cf. R. Pfeiffer, Historia de la filología clásica. Desde los comienzos hasta el final de la época helenística (Madrid 1981) 400-403. 
ra dónde encontramos escrita esta palabra y comparar las realidades espirituales con las espirituales para que lo que indica esta palabra se manifieste de modo más evidente" ${ }^{48}$.

La regla propuesta para elaborar una teología bíblica es extremadamente precisa: no basta comparar textos exteriormente semejantes, sino que es necesario realizar la comparación que enriquece la comprensión del significado de un texto a nivel del sentido profundo, es decir, a nivel del sentido espiritual. Así lo afirma en otro comentario:

"En las palabras del Apóstol, se debe observar de qué manera uno es instruido por el Espíritu: "Comparando, pues, realidades espirituales con realidades espirituales». En el hecho de examinar este término con este término $(\lambda \dot{\varepsilon} \xi 1 \zeta)$, y confrontar lo semejante ( $\tau \dot{\alpha}$ ö $\mu \mathrm{ol \alpha})$, de algún modo se desvela el sentido (voṽs) de las escrituras. Pues así entiendo las cosas de Dios y así adquiero la enseñanza del Espíritu. No solo porque se aprenden las cosas del Espíritu que movió a Isaías, sino también por el hecho de tener el mismo Espíritu que encerró y que veló las palabras de Isaías. De este modo, si el Espíritu no abre las palabras de los profetas, no se pueden abrir las cosas cerradas" ${ }^{39}$.

Es necesario comparar los mismos términos en diferentes pasajes de la escritura (1Co 2,13). Ahora bien, como la coherencia no se da a nivel de la letra ( $\lambda \dot{\varepsilon} \xi 1 \varsigma)$, sino del sentido espiritual (voṽs), las cosas que se muestran semejante (ö $\mu \mathrm{ol \alpha}$ ) entre un texto y otro indica el sentido espiritual de las escrituras, es decir, la enseñanza del Espíritu. Pero solo si se posee el Espíritu que movió al profeta, es posible comprender las palabras del profeta.

En su comentario al salmo primero, Orígenes presenta la enseñanza de un hebreo, posiblemente uno que se había vuelto cristiano ${ }^{50}$, que comparaba la escritura con una única casa con muchas habitaciones en que la llave de la puerta de un cuarto está en la puerta de otro cuarto, para decir, que la clave interpretativa de un texto se encuentra en los otros textos, y luego reconoce la semejanza de este método con el versículo de Pablo de 1Co 2, 13. Es decir, no dice que el método lo haya

48 Orígenes, In Sal. hom., XXXVI, I,1 (Prinzivalli, 32). Cf. 1Co 2, 13.

49 Orígenes, In Ef. Com., 11 (Pieri, 72).

50 Porque este (¿mismo?) hebreo realiza una interpretación trinitaria de Is 6,1 , lo que muestra su carácter cristiano, cf. ORÍGenes, Princ., I, 3, 4; IV, 3, 14; In Is. hom., I, 2; IV, 1; IX; In Nm. hom., XIII, 5. Cf. F. Cocchini, Il Paolo de Origene, p. 120. 
aprendido del hebreo, sino que encuentra analogías entre el método del hebreo y el método que Orígenes ve en el texto paulino. De todos modos, una neta diferenciación entre ambiente judío y helenístico en Alejandría, es inadecuada.

\section{b. "La ley es espiritual" (Rom 7, 14)}

Según la documentación disponible, este versículo no había sido utilizado antes con fines exegéticos ${ }^{51}$. Orígenes comprende la sentencia de Pablo como una verdadera regla de interpretación. Así se expresa en una homilía sobre el Génesis, en que explica la problemática historia de Abimelek, Sara y Abraham:

"Si uno quiere oír y entender estas cosas solo en su sentido literal, debe ponerse a la escucha de los judíos más que de los cristianos; pero si quiere ser cristiano y discípulo de Pablo, óigale decir: «La ley es espiritual» y, cuando habla de Abraham, de su mujer y de sus hijos, escúchele declarar que "estas cosas son alegóricas»; y si cualquiera de nosotros no puede descubrir con facilidad de qué tipo de alegoría se trata, ore para que sea descorrido el velo de su corazón" 52 .

Nuevamente, se presenta a Pablo como maestro de interpretación bíblica $^{53}$. El discípulo de Pablo debe saber que la ley es espiritual y que esos relatos tienen un significado alegórico. En este caso, el relato, en su sentido literal, es inmoral, y solo la interpretación espiritual, según Orígenes, permite salvar el texto en un ambiente polémico: el marcionita rechaza el AT, el pagano ridiculiza la escritura y el simplón cree cosas absurdas.

\section{c. "La letra mata, el espiritu de vida" $(2 \text { Co 3, 6) })^{54}$}

Son muchos los textos en que Orígenes alude a "La letra que mata" de 2Co 3, 6, en contexto exegético. La letra que mata no se refiere al AT,

\footnotetext{
51 Cf. F. Cocchini, Il Paolo di Origene, 125.

52 Orígenes, In Gen. hom., VI,1 (GCS, VI 66).

53 Según Orígenes, esta convicción es común también a los profetas y a los sabios, cf. Orígenes, Rom.Com., VI,vii (1071AB).

54 Cf. Orígenes, In Rom. Com., II,xi (917AB). De acuerdo a nuestra documentación, este versículo, como criterio exegético, no está presente en las obras alejandrinas, sino a partir de Cesarea.
} 
sino a la comprensión torpe de la escritura, sea del AT como del NT. Es decir, también las palabras de Jesús pueden ser letra que mata:

"Todos los judíos que en aquel tiempo escucharon al Salvador, lo escucharon torpemente y, por lo mismo, no creyeron. Hasta hoy, ¡cuántos hay que escuchando las escrituras no han oído la palabra espiritual, que es ligera, sino que escuchan torpemente la letra, que es pesada y mata!" 55 .

Pero ¿cuál es la letra que mata? El inicio de las homilías sobre el Levítico ofrece una clave:

"Tal como en los últimos días, la Palabra de Dios fue recubierta con el velo de la carne, en otro tiempo estaba cubierta con el velo de la letra, en modo que se examine la letra tal como la carne, y se perciba el sentido espiritual que está oculto, tal como [está oculta] la divinidad [en la carne]. Esto es lo que nos encontramos al tratar el libro del Levítico, en que se describe las diversidades de los ritos y de las ofrendas, y los oficios de los sacerdotes. Y esto, que es como la carne de la Palabra de Dios y el revestimiento de su divinidad, lo contemplan y escuchan, según la letra, tanto los dignos como los indignos. Pero, felices aquellos ojos que ven el Espíritu divino interior, oculto en el revestimiento de la letra; y felices los que, al escuchar esto, lo acogen con los oídos puros del hombre interior. Y por el contrario, en estas palabras perciben abiertamente «la letra que mata» $(2 \mathrm{Co} 3,6) " 56$.

A continuación, explica en qué consiste la letra que mata:

"En efecto, si yo siguiera la comprensión simple, como algunos de los nuestros, y acogiera la voz del legislador sin ningún truco de palabra, como ellos suelen ridiculizar, y sin sombra de alegoría, yo, hombre de Iglesia, que vivo bajo la fe de Cristo, y estoy situado en medio de la Iglesia, estaría obligado, por la autoridad del precepto divino, a sacrificar terneros y corderos, y ofrecer flor de harina, con incienso y aceite. Pues, esto hacen los que nos empujan a estar al servicio de la letra de la historia y a observar la letra de la ley" ${ }^{57}$.

El paralelismo entre la letra y la carne de Cristo de la escritura implica que tanto Cristo como la escritura exigen diversos niveles de lectura. No se debe ver aquí una visión negativa de la carne y de la letra, pues según

\footnotetext{
55 Orígenes, In Is. hom., VI,6 (Biblioteca de Patrística 89, 113).

56 Orígenes, In Lv. hom., I,1 (GCS, VI 280).

57 Orígenes, In Lv. hom., I,1 (GCS, VI 280-281).
} 
Orígenes, la letra y la carne son necesarias. No se accede a lo espiritual, sino por medio de lo sensible. Todo el Comentario al Cantar de los cantares gira en torno a esta idea:

"El alma, mientras se encuentra en la casa de este cuerpo, no puede captar la Sabiduría de Dios desnuda y descubierta, sino que contempla las realidades invisibles e incorpóreas, a través de ciertas copias, indicios e imágenes de las cosas visibles" ${ }^{\prime 2}$.

Ahora bien, la letra, la carne, que es necesaria, es también como ambigua: sin ella no se accede al espíritu, pero ella encierra el riesgo de servir la letra y la carne. Asimismo, al comentar las aguas de Mará, que por la vara se vuelven potables, Orígenes afirma:

"Para que pueda ser bebida este agua de Mará, muestra Dios una vara, para que sea introducida en ella, de modo que el que beba no muera, no sienta su amargura. Por ello nos consta que, si alguno quiere beber de la letra de la Ley sin el árbol de la vida, esto es, sin el misterio de la cruz, sin la fe de Cristo, sin inteligencia espiritual, entonces morirá por exceso de amargura. Sabiendo esto el Apóstol, decía: «La letra mata»; esto es, dice abiertamente que el agua de Mará mata, si no se bebe transformada y convertida en dulzura" 59 .

Las aguas de Mará, que son amargas y matan, son también la fuente de vida en el desierto: son amargura y dulzura. Así, las mismas aguas, es decir, la misma letra, son fuente de muerte y de vida. De este modo, para Orígenes, la misma realidad es letra que mata y espíritu que da vida. Pues lo que mata no es la letra, sino el modo de comprender la letra.

\section{d. "Toda escritura es útil" (2Tim 3, 16)}

La utilidad de toda escritura no es un dato que se manifieste de modo inmediato al lector, sino más bien una convicción de fe, que se deduce de la inspiración. De hecho, Orígenes sostiene que un inexperto lector, cuando lee el libro de los Números, juzgará que algunos pasajes no le sirven para nada y los rechaza rápidamente ${ }^{60}$. Frente a uno de estos textos difíciles, esta vez del libro de los Jueces, afirma:

\footnotetext{
58 Orígenes, In Ct. Com., III,14, 19 (GCS VIII, p. 220, 7-11).

59 Orígenes, In Ex. hom., VII, 1 (GCS, VI 206).

60 Cf. Orígenes, In Nm. hom., XXVII, 1.
} 
"Puesto que toda Escritura, siendo inspirada por Dios, es útil, respecto a estos pasajes, debes aceptar una de dos: o que no son inspirados por Dios, porque no son útiles, como supondría el incrédulo; o bien, como creyente, aceptar que son útiles porque son inspirados"61.

Según Orígenes, la utilidad de toda la escritura se deduce de su carácter inspirado. De este modo, establece sobre la base del texto de Pablo, un principio hermenéutico: todo texto bíblico es útil, es decir, es edificante, beneficia al lector. Y así, cuando se lee un texto y no se encuentra utilidad en él, es porque no se lo ha comprendido. Este principio le sirve para pasar del sentido literal al espiritual: en muchas ocasiones, cuando la letra de un texto parece que no ofrece utilidad, retóricamente, se pregunta: ¿De qué me aprovecha? Por ejemplo, cuando se habla del corazón blando o limpio, la comprensión espiritual no ofrece beneficio, mientras la espiritual sí. Por eso, al explicar Is 7, 14, declara: "Estas cosas han sido dichas no a la Casa de David, sino a nosotros" 62.

3. Pablo, ejemplo del que ha recibido la gracia para comprender la escritura La exégesis espiritual, para Orígenes, es estrictamente espiritual, es decir, es un don del Espíritu. El Alejandrino destaca que para comprender la escritura es necesaria la ejercitación, la aplicación y la constancia, e insiste simultáneamente en la necesidad del don del Espíritu, pues el acceso a los misterios no es una simple obra humana. Por ello, mientras realiza su actividad exegética ruega por el don del Espíritu ${ }^{63}$. Con estas convicciones de fondo, presenta a Pablo como modelo del hombre que, por haber recibido la gracia, comprende la Palabra de Dios:

"Y si nos aproximamos a los evangelios, también su comprensión exacta, puesto que es la de Cristo, requiere de la gracia que ha sido concedida al que dijo: "Pero vosotros tenéis la comprensión de Cristo, para que conozcamos lo que nos ha sido regalado por Dios. Y hablamos esto, no con palabras aprendidas de la sabiduría humana, sino con [palabras] aprendidas del Espiritu»" ${ }^{64}$.

Naturalmente, Pablo no es el único maestro de exégesis. Orígenes cree que la gracia inspira al intérprete la comprensión del texto sagrado

\footnotetext{
${ }_{61}$ Phil XII,2 (Robinson, 63, 23-27). El texto corresponde a In Jos. hom., XX, 2.

62 Orígenes, In Is. hom., II,1 (Biblioteca de Patrística 89, 67).

63 Cf. Orígenes, In Ex. hom., I,1.

64 Orígenes, Princ., IV, 2, 3 (GCS, V 310); 1Co 2, 16. 12-13.
} 
a veces de modo directo y otras veces por medio de otro. Así lo afirma en un interesante pasaje, en que enfrenta un problema de crítica textual, que contiene válidos elementos de método para la teología bíblica:

"Cuando no entendemos lo que se ha dicho [en la Escritura], ni lo corrijamos, ni optemos por lo más fácil, sino que esperemos para que la gracia de Dios nos sugiera, por la iluminación del conocimiento, la explicación de las dificultades; o bien, al menos, por medio de quien quiera, la gracia de Dios nos ilumine nuevamente para que ya no investiguemos, sino que nuestra dificultad sea resuelta. Pero si queremos obtener la comprensión sin Dios, rápidamente nosotros mismos nos lamentaremos" 65 .

Muchos otros maestros pueden ayudar a comprender el texto bíblico. Pero, a diferencia de ellos, Pablo no es presentado por Orígenes como uno que sugiere el contenido de determinados versículos, sino como el modelo del lector que comprende que la ley espiritual (Rom 7, 14), que reconoce que la ley contiene la sombra de los bienes futuros (Heb 10, 1), y que comprende la escritura con la ayuda del Espíritu Santo ${ }^{66}$.

\section{Conclusión}

Llega el momento reunir los frutos de la presente investigación.

1. Los casos de interpretación simbólica en la obra de Pablo están a la vista, pero la novedad de Orígenes es aplicar estos casos de modo sistemático, es decir, transforma algunos casos de interpretación simbólica que encuentra en Pablo en una verdadera regla de hermenéutica, pues afirma que Pablo propone estos ejemplos para que la escritura en su totalidad sea comprendida con el mismo método. Según Orígenes, el apóstol no solo aclara tal o cual punto, sino que enseña cómo se debe leer la escritura en la Iglesia, tanto el AT como el NT.

2. El carácter fuertemente polémico del contexto de Orígenes muestra que el recurso a la interpretación espiritual es una necesidad urgente. No hay aquí una discusión de dos escuelas de hermenéutica bíblica, sino que está en juego la aceptación o el rechazo del AT, es decir, está en juego la idea de Dios y la fisonomía de la Iglesia. Orígenes está convencido que solo por medio de la exégesis espiritual es posible ser fiel a la regla de fe

65 Orígenes, In Is. hom., II, 1 (Biblioteca de Patrística 89, 66-67).

66 Cf. Orígenes, Princ., IV, 2, 4; IV, 3, 12; IV, 3, 14. 
que acepta tanto el AT como el NT. Además, la polémica no solo viene de afuera, sino que surge también desde dentro de la asamblea.

3. Movido por la convicción de fe de la inspiración, Orígenes tiene certeza de la coherencia, relevancia y utilidad de la escritura. Pero esta coherencia, relevancia y utilidad no siempre se verifica a nivel literal. Por ello, considera indispensable recurrir a la comprensión espiritual: en muchos casos, solo la comprensión espiritual permite a Orígenes mostrar el carácter benéfico de relatos que, a nivel de la letra, se muestran contradictorios, inútiles, absurdos o inmorales. Asimismo, Orígenes puede practicar el método de la comparación de textos bíblicos, porque está convencido de que la inspiración asegura la coherencia de toda la escritura.

4. Finalmente, aparece claro el carácter específicamente espiritual de la exégesis espiritual. Por el hecho que el Espíritu Santo tiene un real protagonismo en la comprensión de la escritura inspirada: si el Espíritu no abre las palabras, ellas permanecen cerradas. 
Resumen: El presente artículo busca mostrar hasta qué punto la exégesis bíblica de Pablo influenció a Orígenes de Alejandría. Para ello, en primer lugar, se busca aclarar los motivos que impulsaron a Orígenes a interpretar la Escritura de modo simbólico y sus tensiones con los partidarios de su lectura literal. Luego, se presenta la relevancia de Pablo en la teoría exegética origeniana, en especial, por medio de un texto clave: De principiis IV,2. Y, finalmente, se estudia el uso de los versículos paulinos en que Orígenes reconoce ciertas reglas de exégesis bíblica (1Co 2, 13; Rom 7, 14; 2Co 3, 6; 2Tim 3, 16).

Palabras clave: Pablo, Orígenes de Alejandría, De principiis, Historia de la exégesis.

Abstract: The article aims to illustrate how Paul's biblical exegesis influenced Origen of Alexandria. At first, it seeks to clarify the reasons that led Origen to interpret Scripture symbolically and the tensions with supporters of literal exegesis. Then, it presents the relevance of Paul in Origen's exegetical theory, especially through a key text: De principiis IV, 2. And finally, the article studies the interpretation of Pauline verses in which Origen recognizes certain rules of biblical exegesis.

Keywords: Paul, Origen of Alexandria, De principiis, History of exegesis. 
